\title{
Internal biosecurity between islands: identifying risks on pathways to better manage biosecurity threats
}

\author{
M.R. McNeill ${ }^{1}$, C.A. Dowsett ${ }^{2}$, L.T. Aalders ${ }^{2}$, T.K. James ${ }^{2}$, P.M. Bradbury ${ }^{3}$ and S.R. Palmer ${ }^{4}$ \\ ${ }^{1}$ AgResearch, Lincoln, Private Bag 4749, Canterbury 8140, New Zealand \\ ${ }^{2}$ AgResearch, Ruakura Research Centre, Private Bag 3123, Hamilton 3240, New Zealand \\ ${ }^{3}$ SPS Biosecurity Ltd, PO Box 45, Amberley, New Zealand \\ ${ }^{4}$ Environment Canterbury, PO Box 7, Amberley, New Zealand \\ Corresponding author: mark.mcneill@agresearch.co.nz
}

\begin{abstract}
The Chatham Islands possess several endemic vertebrate, invertebrate and plant species and are free of many pests found on mainland New Zealand. Keeping out unwanted organisms that may threaten the agricultural sector on the islands is important for the local economy. Research found that soil intercepted from used machinery destined for the Chatham Islands contained a range of plants, insects and nematodes, but the number and diversity of these taxa varied with the source of contamination. Sampling of Chatham Island pasture, indicated an absence of Sitona obsoletus, but the presence of other insect species including porina and Irenimus aequalis that originated from mainland New Zealand. Despite being some $750 \mathrm{~km}$ from New Zealand, transport routes allow for the movement of unwanted and invasive invertebrate species to the islands. Identifying dispersal pathways and instigating appropriate management plans compatible with an existing biosecurity programme, will reduce the flow of invertebrate and plant pests.
\end{abstract}

Keywords plant biosecurity, pasture pests, Chatham Islands, porina, Argentine stem weevil, Irenimus aequalis, risk analysis.

\section{INTRODUCTION}

The Chatham Islands (Rekohu, Wharekauri) lie approximately 750 kilometres east of the South Island of New Zealand. The 11 islands cover a total of 966 square kilometres, almost all of which comprises the two main islands of Chatham Island and Pitt Island. These are the only inhabited islands, the remaining smaller islands being conservation reserves with restricted or prohibited access. The livelihoods of the residents mainly depend on fishing, agriculture and tourism. Regular shipping and air flights provide the main transport routes between New Zealand and the main Chatham Island, on which the current vegetation comprises large areas of fern and pasture, along with dense forest, peat bogs and other habitats. The islands are home to a rich biodiversity including endemic plants, birdlife and invertebrates. Because of the Chatham Islands' isolation and the absence of many pests and diseases found in mainland New Zealand, there is widespread recognition that the Chatham Islands have a distinctive ecosystem. An active biosecurity programme is managed by the Chatham Island Council and administered by Environment Canterbury, to prevent the entry of unwanted organisms. 
However, baseline data about the occurrence of some pests on the Chatham Islands are lacking. The Department of Conservation monitors for the presence of potential conservation pests and weeds, and there is regular quarantine and risk site surveillance undertaken by SPS Biosecurity as well as irregular collection surveys conducted by Crown Research Institutes. However, there are gaps in the surveillance programme for the marine environment, animal pathogens and many agricultural pests.

Past surveys of the invertebrate species on the islands have identified the presence of both endemic and exotic species (MacFarlane 1979; MacFarlane et al. 1991; Emberson 2003; Curtis 2011; Goldberg \& Trewick 2011). The exotic species include mainland New Zealand native invertebrates species, such as porina and grass grub, along with invasive alien species, such as the weevils Listronotus bonariensis (Argentine stem weevil, ASW), Otiorhynchus sulcatus and Steriphus diversipes lineata.

This paper reports on research to obtain baseline data from contaminated agricultural equipment or soil that would aid the Chatham Islands council and biosecurity operators to understand the potential threats posed to their pastures. The underlying premise was that the islands are free of many arthropod pests and weeds that would impact on pastoral production. Less is known of the nematode species found on the islands but there are several plant parasitic nematode species found in New Zealand that impact on pasture productivity (Watson \& Mercer 2000; Mercer et al. 2008), and ideally should be prevented from reaching the Chatham Islands. While there seems to be a good understanding of the weed species present in the Chatham Islands (S.R. Palmer, Environment Canterbury, personal communication), less is known about the insect pests. While unverified, it is believed that the islands are currently free from the clover pest Sitona obsoletus (clover root weevil, CRW), the little fringed weevil (Atrichonotus taeniatulus), white fringed weevil (Naupactus leucoloma) and clover flea (Sminthurus viridis). Conversely, ASW, black vine weevil (Otiorhynchus sulcatus), strawberry weevil Otiorhynchus ovatus (Emberson 2003) and wheat bug, Nysius huttoni (MacFarlane 1979) are reported to be present on the Islands. A key component of risk analysis is to first establish which pests and weeds are already present on the Chatham Islands.

\section{MATERIALS AND METHODS}

\section{Soil intended for Chatham Islands}

A large volume of soil (ca 10 tonnes), earmarked for shipment to the Chatham Islands for use as fill for access tracks in a pastoral environment, was sampled for insects, nematodes and weeds to assess the biosecurity threat prior to shipping. The heap was located at a Timaru transport depot, comprised an accumulation of soil collected from various locations in mid-Canterbury over a period of weeks, was located on waste ground and covered and surrounded by weedy plants. Soil had recently been removed for another project, so there was an exposed face resulting from this activity. The pile was sampled on 25 March 2013 with soil collected from five locations at irregular intervals across the heap. One bag comprised soil collected from top of the heap amongst volunteer weeds (location 1), three points along the exposed face of the heap (locations 2-4) and from the periphery of the heap (location 5). At each of the five collection sites, the soil was subsampled from 4-5 points (within $2 \mathrm{~m}$ radius of a central point). Soil was placed into $25 \mathrm{~cm} \times 30 \mathrm{~cm}$ polypropylene bags using either a small hand spade or plastic hearth shovel and brush, with the tools cleaned between each sampling location.

\section{Hay rake}

A used hay rake stored outside at a Napier shipping company prior to shipment, was sampled on 10 January 2014. It was examined in situ for any insects or spiders that may have colonised the equipment. Soil and other plant material were removed using either a clean paint scraper or hoof pick, then placed in a plastic bag, labelled and sealed.

\section{Aggregate}

An aggregate stockpile was sampled on 7 May 2014 to determine the potential contamination 
from seeds. The aggregate was located at a Napier business and sourced from an Environment Canterbury approved quarry bounding Ngaruroro River in Hawke's Bay, and was scheduled for use in construction projects on the Chatham Islands. Twenty-one samples, each weighing approximately $1000 \mathrm{~g}$, were collected from several locations on the pile and placed on trays to investigate seedling emergence. In an initial assessment, subsamples of aggregate were placed in 21 trays, transferred to a heated glasshouse, watered and then monitored for seedling emergence. While seedlings were observed, there was very high mortality, which made identification impossible. Therefore, the technique was modified, whereby $500 \mathrm{~g}$ of aggregate from each sample was mixed with $500 \mathrm{~g}$ of sterilised potting mix and spread into seedling propagation trays.

\section{Soil and organic matter intercepted at Chatham Islands}

Used vehicles and farming implements arriving at Waitangi port on the main Chatham Island were inspected and soil contaminants collected by Environment Canterbury staff between 24 May and 6 June 2014. The six samples were received at AgResearch Lincoln on 26 June 2014. The equipment sampled included a stock crate, drilling rig, truck cab, soil collected from a deck of a truck, and a mower, as well bark debris collected from a consignment of firewood that had arrived in bulk storage bags.

\section{Chatham Island pasture insects}

To determine what pastoral pests were on the island, a survey was undertaken on the main Chatham Island 9-12 September 2014. Sampling mainly focussed on assessing the above-ground arthropods, with collections made at seven sites (Table 5) using a blower vac modified to suck insects into a net recessed into the suction tube. In addition, porina caterpillars were collected by digging spade squares from paddocks at Wharekauri (43.7092 S, 176.5987 E), Kaingiroa (43.7331 S, 176.2429 E), Durham (44.0119 S, 176.6725 E) and Tuku (44.0581 S, 176.6272 E). Samples were hand-sorted and insects removed for assessment at AgResearch Lincoln.

\section{General methods for sampling soil contaminants} For the Timaru and Napier collections the substrate being sampled was visually searched for arthropods before a sample was collected. In the laboratory, the soil samples were weighed, and visually examined for arthropods under a binocular scope. Thereafter, samples were processed to extract, count and identify nematodes and plants. For larger samples the soil from each location was mixed thoroughly by hand prior to setting up for nematode extraction and plant rearing. Depending on sample size, 87-100 g of soil was used for nematode extraction. Extraction generally followed the method of Bell \& Watson (2001) using the Whitehead tray extraction method. Each sample was firstly hand-crumbled then placed on to two-ply paper tissue (Tork ${ }^{\circledR}$ Premium, SCA Hygiene Australasia Pty Ltd), supported by two layers of nylon gauze within a plastic shallow tray $(26 \times 21 \times 6 \mathrm{~cm})$ and $500 \mathrm{ml}$ water was added. After $72 \mathrm{~h}$ the soil and tissue were removed and the nematode solution was poured into a $1000 \mathrm{ml}$ plastic beaker, left to settle for 3-4 h, then gently reduced to ca $75 \mathrm{ml}$ volume by removing the supernatant. The $75 \mathrm{ml}$ samples were transferred to $100 \mathrm{ml}$ plastic beakers and allowed to settle for 3-4 $\mathrm{h}$ before reduction to a final volume of $10 \mathrm{ml}$. Nematodes were counted in a Doncaster dish (Doncaster 1962), to provide a total nematode count (fungal, bacterial, omnivore, predator and plant parasitic nematodes). Plant parasitic nematodes were identified morphologically using a light microscope at approximately $50 \times$ magnification and sorted into genera based on the keys of Siddiqi (2000) for Tylenchida, and Bongers (1994) for other groups. Nematodes suspected to be plant pathogenic species were taken for molecular identification. Briefly, DNA was extracted using the prepGEM tissue kit and $18 \mathrm{~S}$ primers consisting of SSU18A (AAAGATTAAGCCATGCATG) (Floyd et al. 2002) and 1138R (TGAGTCAAATTAAGCCGCAGG) (Ross et al. 2010) for Ditylenchus, and 28S primers D2A (ACAAGTACCGTGAGGGAAAGTTG) and D3B (TCGGAAGGAACCAGCTACTA) (Courtright et al. 2000; Kaplan et al. 2000) for Pratylenchus, with amplification carried out using 
a Phusion Hot Start II Hi-Fi DNA polymerase 100 U. Sequencing was carried out by the Massey Genome Service and results compared with BLAST NCBI.

The methodology for rearing of seeds was dependent on the volume of soil collected and in the experiments described above, ranged from 87 to $1300 \mathrm{~g}$. If the volume of the soil was limited $(<100 \mathrm{~g})$, the sample was firstly taken to extract any nematodes, then transferred to trays and held in a glasshouse to allow for germination of viable seeds. For large soil samples, a polystyrene seed tray was half filled with potting mix (Daltons, Matamata, New Zealand) and topped with a layer of weed mat. Each soil sample was spread out on top of the weed mat to a depth of $10 \mathrm{~mm}$. The seed trays were placed on benches in a $\mathrm{PC} 1$ temperature controlled glasshouse at $21^{\circ} \mathrm{C}$, under ambient day:night lighting and were watered as required. The seed bank was allowed to germinate for 8 to 10 weeks before the emerged seedlings were identified by morphology. The total numbers of emerged seedlings were counted for each sample. To account for the varying quantities of soil these values were standardised to the number of emerged seedlings per gram of soil. Apart from premature mortality, seedlings were grown to a size where they were identified to species level. The plant type (e.g. grass or herb) to which the species belonged was classified using several sources (Webb et al. 1988; Edgar \& Conner 2000; Popay et al. 2010; Champion et al. 2012).

\section{RESULTS}

\section{Soil intended for Chatham Islands}

Initial observations recorded that the heap was extensively covered with several weed species, some which were flowering, with only the exposed faces generally free of vegetation. Visual inspection of the soil surface found a range of arthropods (e.g. aphids, Collembola, Nysius huttoni) including a single adult clover root weevil (Sitona obsoletus). No insects were seen in the samples examined in the laboratory.

Seedlings emerged from four of the five samples (Table 1). Of the soil sampled from the pile, the mean ( \pm SEM) across the five locations was $0.02 \pm 0.007$ seeds/g soil, with greatest number of seeds recovered from the top of the pile $(0.04$ seeds/g). There was a total of 20 plant species found in the samples (Table 1), with herb species $(60 \%)$ the dominant plant type, followed by grasses (25\%) and legumes (15\%). Some of the plants observed growing on the soil heap when the samples were taken were not reared in the glasshouse. These included broom (Cytisus scoparius), nodding thistle (Carduus nutans), thorn apple (Datura stramonium) and velvety nightshade (Solanum chenopodioides). This suggests that the seeds were either not present or did not germinate from the samples.

As with the plant data, nematode numbers/g soil were low (Table 2). There was a mean ( \pm SEM) of $2.5 \pm 0.97$ nematodes/g of soil but a range of $0.7-7.8 / \mathrm{g}$ soil from the five locations. Lesion (Pratylenchus) and pin (Paratylenchus) nematodes were the only two genera of plant parasitic nematodes recovered, with a mean $0.3 \pm 0.24$ plant feeding nematodes/g of soil (Table 2). Both genera are common in New Zealand productive systems. A Pratylenchus nematode from the top of the heap sample was molecularly identified as $P$. thornei, which has been found in the Canterbury region before and has a wide host range (Castillo \& Vovlas 2007). The number of nematodes/g soil recovered from the soil heap was substantially lower than the 28.3 nematodes/g and $16.3 \mathrm{~g} / \mathrm{soil}$ of soil for total nematodes and plant parasitic nematode respectively, taken from dairy pasture in Canterbury (M.R. McNeill, unpublished data).

\section{Hay rake}

A mix of soil and plant matter totalling $87.3 \mathrm{~g}$ was removed from the rake. The soil included a portion contaminated with grease. No insects were seen but two spiders were observed to have built webs on the structure of the rake and were removed. In total, 45 plants belonging to five species were germinated from the sample with approximately 0.5 seeds/g of soil. In order of abundance the plant species were Lolium perenne (33 plants), Poa trivialis (4), Plantago 
Table 1 The number of plants and main plant taxa grown from samples collected from a soil pile near Timaru.

\begin{tabular}{ccccc}
\hline $\begin{array}{c}\text { Sampling } \\
\text { location }\end{array}$ & Soil weight $(\mathrm{g})$ & Total plants/sample & Number species/sample & Total plants/g \\
\hline 1 & 838 & 35 & 11 & 0.042 \\
2 & 1298 & 15 & 6 & 0.012 \\
3 & 981 & 20 & 12 & 0.020 \\
4 & 1193 & 0 & 0 & 0.000 \\
5 & 1220 & 11 & 8 & 0.009 \\
\hline Plant Taxa & Plant Identification & & \\
Grasses & Eleusine indica, Elytrigia repens, Festuca ruba, Lolium multiflorum, Poa trivialis \\
Broadleaf & Anthemis cotula, Aphanes inexpectata, Capsella bursa-pastoris, Cerastium fontanum, \\
& Chenopodium album, Crepis sp., Epilobium nummulariifolium, Lepidium didymum, \\
Regume & Trifolium dubium, Trifolium repens, Trifolium subterranean & \\
\hline
\end{tabular}

Table2 Nematodes recovered from samples collected from a soil pile near Timaru.

\begin{tabular}{ccccc}
\hline Sample location & $\begin{array}{c}\text { Total } \\
\text { nematodes }\end{array}$ & $\begin{array}{c}\text { Total plant parasitic } \\
\text { nematodes }\end{array}$ & $\begin{array}{c}\text { Total number } \\
\text { nematodes/g }\end{array}$ & $\begin{array}{c}\text { Plant } \\
\text { nematodes/g }\end{array}$ \\
\hline 1 & 780 & 132 & 7.76 & 1.31 \\
2 & 92 & 4 & 0.91 & 0.04 \\
3 & 124 & 12 & 1.23 & 0.12 \\
4 & 172 & 0 & 1.71 & 0.00 \\
5 & 72 & 4 & 0.72 & 0.04 \\
\hline
\end{tabular}

lanceolata (narrow leaved plantain) (3), Leontodon taraxacoides (hawkbit) (3) and Rumex obtusifolius (broad leaved dock) (2). There was a total of 504 nematodes recovered, with ca 6 nematodes/g of soil. The nematodes were mainly bacterial feeders belonging to a mix of genera, and no plant parasitic nematodes were found.

\section{Aggregate}

In total, 11 seeds from six species were recovered from a total of $10.5 \mathrm{~kg}$ of aggregate, being only 0.001 seeds/g of aggregate (Table 3 ).

\section{Soil and organic matter intercepted at Chatham Islands}

The used vehicles and farming implements originated from Hawke's Bay, Bay of Plenty, Canterbury and Southland, with the samples weighing between 89 to $500 \mathrm{~g}$ (Table 4). Along with soil, the samples consisted of small stones, fresh or decaying plant material including corms, lichen, moss, animal manure, insect body parts, animal fibres and live insects. The live insects comprised eight Lepidopteran larvae, two small beetles and three small dipteran flies and were recovered from a tractor originating from Southland. Attempts to identify the Lepidopteran larvae were unsuccessful, attributed in part to gaps in the taxonomic knowledge for immature stages of New Zealand Lepidoptera (Robert Hoare, Landcare Research, personal communication). The mean number $( \pm$ SEM) of plants grown and number of species per sample was $19 \pm 6.5$ and $4.2 \pm 1.0$, respectively. The number of plants/g of soil ranged from 0.02 to 0.47 plants $/ \mathrm{g}$, being lowest in the firewood debris and highest in the sample recovered from the 
Table 3 Number and identification of plants grown from aggregate sourced from approved quarry bounding Ngaruroro River in Hawke's Bay.

\begin{tabular}{|c|c|c|c|c|}
\hline $\begin{array}{l}\text { Number of } \\
\text { samples }\end{array}$ & $\begin{array}{l}\text { Sample weight } \\
\text { (g) }\end{array}$ & $\begin{array}{l}\text { Mean number plants/ } \\
\text { sample }\end{array}$ & $\begin{array}{l}\text { Plants/g } \\
\text { aggregate }\end{array}$ & $\begin{array}{c}\text { Mean number species/ } \\
\text { sample }\end{array}$ \\
\hline 21 & 500 & 0.5 & 0.001 & 1 \\
\hline Plant Taxa & \multicolumn{4}{|c|}{ Plant identification } \\
\hline Grasses & \multicolumn{4}{|c|}{ Digitaria sanguinalis (summer grass), Juncus bufonius (toad rush) } \\
\hline Broadleaf & \multicolumn{4}{|c|}{$\begin{array}{l}\text { Cyperus sp. (sedge), Veronica anagallis-aquatica (water speedwell), Veronica } \\
\text { serpyllifolia (turf speedwell) }\end{array}$} \\
\hline Legume & \multicolumn{4}{|c|}{ Trifolium dubium (suckling clover) } \\
\hline
\end{tabular}

mower (Table 4). Overall there were seven grass and 12 herb species recovered from the samples (Table 4). While none of the plant species was on the Chatham Island unwanted species list, the results suggest that contaminated machinery does provide a pathway for the entry of unwanted plant species.

Nematodes were present in all samples, with between 0.1-145 nematodes/g of soil (Table 4). The mean total number $( \pm$ SEM) of nematodes per sample was $5754 \pm 2629$.9. Plant pathogenic nematodes were only found in two samples, one originating from Canterbury and the other from Southland. Molecular identification indicated the presence of Ditylenchus dipsaci Kuhn and Ditylenchus adasi (Sykes). Ditylenchus dipsaci primarily infects onion and garlic but has a wide host range (Knight et al. 1997), while information on $D$. adasi host range is limited.

\section{Chatham Island pasture insects}

Overall, 77\% of the weevils collected from pasture or recreational areas comprised ASW, followed by Irenimus aequalis (21\%), Sitona discoideus (2\%) and a single Irenimus unidentified specimen possibly compressus (Table 5). Sitona obsoletus, the little fringed weevil (Atrichonotus taeniatulus) and whitefringed weevil (Naupactus leucoloma) were not detected. While Irenimus aequalis was already confirmed on mainland Chatham Island (Emberson 2003), molecular analysis of these specimens showed that the population was closely matched to populations found on Banks Peninsula, Canterbury (S. White, Lincoln University, personal communication). Dissection of ASW found that the population was parasitised by Microctonus hyperodae, an endoparasitoid first released on mainland New Zealand in 1991 (McNeill et al. 2002). None of the I. aequalis $(\mathrm{n}=29)$ nor $S$. discoideus $(\mathrm{n}=3)$ were parasitized. Soil coring found porina (Wiseana spp.) widely established across the island, while grass grub was relatively rare. Molecular analysis of the porina specimens showed that there are two species, one each from the North and South Islands (N.K. Richards, AgResearch, unpublished data).

\section{DISCUSSION}

This research aimed to provide quantitative information on the biological risks associated with contaminated freight or other products, such as aggregate, which may provide a pathway for entry of unwanted organisms. These results help organisations involved in Chatham Islands biosecurity to develop strategies to manage invasion pathways and protect the Chatham Islands pastoral industry and native ecosystems from future biosecurity threats. This study showed that when these examples are taken individually, a risk ranking would indicate that the soil intercepted off machinery posed a higher risk to the Chatham Islands pastoral farming compared to aggregate, which represented a low risk. The former was found to contain live insects, as well as many viable seeds and nematodes which may pose a risk. Conversely, the aggregate was deemed low risk because of relatively sterile nature of the shingle. Risk is further diminished by the use of much of the aggregate in construction projects on the islands. 


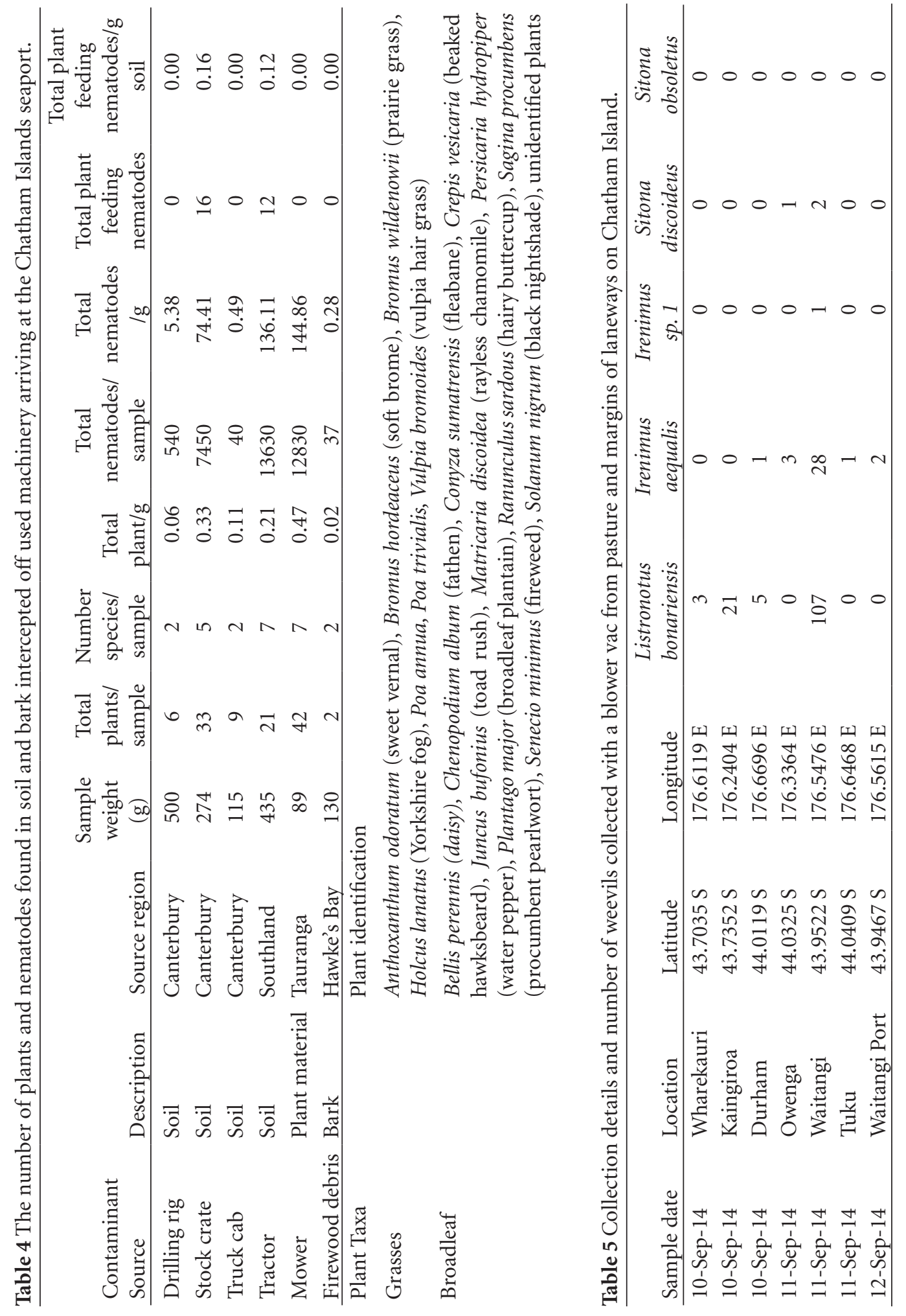


None of the plants grown in these studies were on the Chatham Islands unwanted plants list (Chatham Islands Council 2008), although nodding thistle (Surveillance Control status) and broom (Total Control) were found growing on or near the soil heap at the Timaru site. However, these studies did confirm that contaminated used machinery and soil are a viable pathway for unwanted plants. Nematodes are generally overlooked in biosecurity strategies because they are not immediately obvious and require specialist skills to extract and identify. Of the plant pathogenic species found in these samples, Ditylenchus and Pratylenchus species have a broad host range and have been associated with agricultural, horticultural and crop plants. Paratylenchus species in New Zealand are more commonly found with grass species, including native tussocks and fruit trees (Knight et al. 1997). Both have also been found in soil from native tussock grasslands (Bell et al. 2005). Pratylenchus are migratory endoparasites and can either cause damage directly by their feeding or allowing secondary infection by bacteria or fungi through the root lesions they create (Duncan \& Moens 2006). Paratylenchus are migratory ectoparasites that are also known to cause plant damage (Hooper \& Evans 1993). It is not known what plant parasitic species of concern to pastoral farming are already present on the Chatham Islands.

Although geographically isolated, the physical connections arising from trade and tourism between the Chatham Islands and mainland New Zealand provide risk pathways by which agricultural pests can arrive. Some of these pathways can be managed more easily (e.g. stopping the shipping of hay) than others (e.g. used agricultural equipment) and some may not be able to be managed effectively at all (e.g. online trading). However, the isolation of the Chatham Islands will be a major contributing factor in developing some practical measures to exclude pests. In addition, consideration must be given to potential changes in agricultural practices, such as intensification of pastoral operations, changes in animal types being farmed and the introduction of higher yielding plant species and cultivars. These changes could significantly lift productivity, but conversely could lead to greater susceptibility to pests either present or able to invade and survive on the Chatham Islands. The potential impacts of climate change on invasive species should also not be overlooked as this can have varied impacts including establishment of new invasive species, altered impact of existing invasive species (sleeper pests) and altered effectiveness of control strategies (Hellmann et al. 2008; Gerard et al. 2013).

For the Chatham Islands Council, implementation of strategies that stop the spread of new species or strains of existing pests (e.g. those that are resistant to pesticides or more virulent), reduces production costs, enhances profitability and minimises environmental impacts to farmers. The weight of evidence suggests that quarantine measures preventing the arrival of new species is the least expensive and most effective method for managing invasive alien species (e.g. Wittenberg \& Cock 2001; Venette \& Koch 2009; Moore et al. 2010).

Because of the limited routes to the Chatham Islands, the main pathways for agricultural pests to reach the islands can be identified. While some of these may not be currently active and new pathways may open up in the future, developing an understanding of these pathways provides a starting point to look at risk. Risk of insect pest or weed introduction may consider the type of freight, regional origin and timing of freight movements to the Chatham Islands in relation to the biology of insect or weed pest, and storage time prior to transport. For example, the movement of agricultural machinery to the Chatham Islands in spring-summer coincides with a period when many key pests such as CRW or lucerne weevil are flying. Therefore, risk is probably highest in the November to March period when the mobile adults are often dispersing, reproductively mature and mobile. Additionally, as these insects are very good hitchhikers (Ferguson et al. 2012), the risk that they could enter the pathway and be inadvertently carried to the Chatham Islands is increased. For weeds and nematodes, the risk window covers a wider period, with the chances 
of establishment generally higher because of an ability to remain dormant until conditions are favourable for growth. In terms of risk assessment, the way an organism may enter the islands (entry assessment), ability to move from carrier to suitable host or habitat (exposure assessment), the consequences of establishment (consequence assessment) and economic cost (economic assessment), all need to be considered. Quantifying the volume of freight moving along the key pathways would be useful to developing a profile for the highest risk pest/pathway combinations as indicated by freight volume $\times$ contamination viability $\times$ impact $\times$ season. An example of a risk assessment template is shown in Figure 1. Although the numbers are conceptual, this shows how pests and pathways can be ranked to assist in risk prioritisation. The template shows how quarantine-based interventions can prevent multiple pest threats from entering the pathway. The challenge for quarantine inspectors is an awareness of the potential risk organisms, the steps required to prevent contamination and what to look for when carrying out an assessment.

The presence of the ASW parasitoid, M. hyperodae, which was first released in 1991, indicates that there has been at least two introductions of ASW to the islands, the latter introducing the parasitoid. Similarly, the presence of populations of porina from both North and South Islands indicate at least two separate introductions following human occupation, although wind assisted dispersal from mainland New Zealand cannot be totally discounted. Irenimus aequalis has also been introduced to the Chatham Islands. As a flightless species, its presence on the Chatham Islands is indicative of human-assisted travel.

In conclusion, agriculture is an important activity on the Chatham Islands worth ca $\$ 5 \mathrm{M}$ pa (cf $\$ 21 \mathrm{M}$ for fishing) and there appear to be opportunities for the farming sector to draw increased benefit from farming in a relatively pestfree environment, compared to mainland New Zealand. Current insect pests and weeds already have a negative impact on pasture productivity and persistence, which directly affects animal productivity. Therefore, preventing unwanted organisms arriving to the islands is preferable to having to undertake expensive eradication and/ or long term pest management programmes. In addition, excluding these unwanted organisms provides the opportunity to maximise any benefits that arise from future improvements or changes in pastoral systems. Developing a quarantine system that targets agricultural pests is entirely complementary with the current Chatham Islands border biosecurity programme aimed at preventing the arrival of vertebrate pests and weeds, therefore could be implemented within the current biosecurity framework.

\section{ACKNOWLEDGEMENTS}

Our thanks to Mark Hansen and Sophie Meller (of SPS Biosecurity) for their support in the work carried out in Napier and Kerri Moir (Environment Canterbury) for collection of samples from Chatham Island sea port. Thanks also to Dr John Kean (AgResearch/ Better Border Biosecurity) for the development of the pathways risk template and editorial comment on an earlier draft of this manuscript.

\section{REFERENCES}

Bell NL, Watson RN 2001. Optimising the Whitehead and Hemming tray method to extract plant parasitic and other nematodes from two soils under pasture. Nematology 3: 179-85.

Bell NL, Davis LT, Sarathchandra SU, Barratt BIP, Ferguson CM, Townsend RJ 2005. Biodiversity of indigenous tussock grassland sites in Otago, Canterbury and the Central North Island of New Zealand II. Nematodes. Journal of the Royal Society of New Zealand 35: 303-319.

Bongers, T 1994. De Nematoden van Nederland. Koninklijke Nerlandse Natuurhistorische Vereniging, Utrecht. 408 pp.

Castillo P, Vovlas N 2007. Pratylenchus (Nematoda: Pratylenchidae): Diagnosis, Biology, Pathogenicity and Management. In: Hunt DJ, Perry RN ed. Nematology Monographs and Perspectives, Vol. 6. Brill, Leiden. 


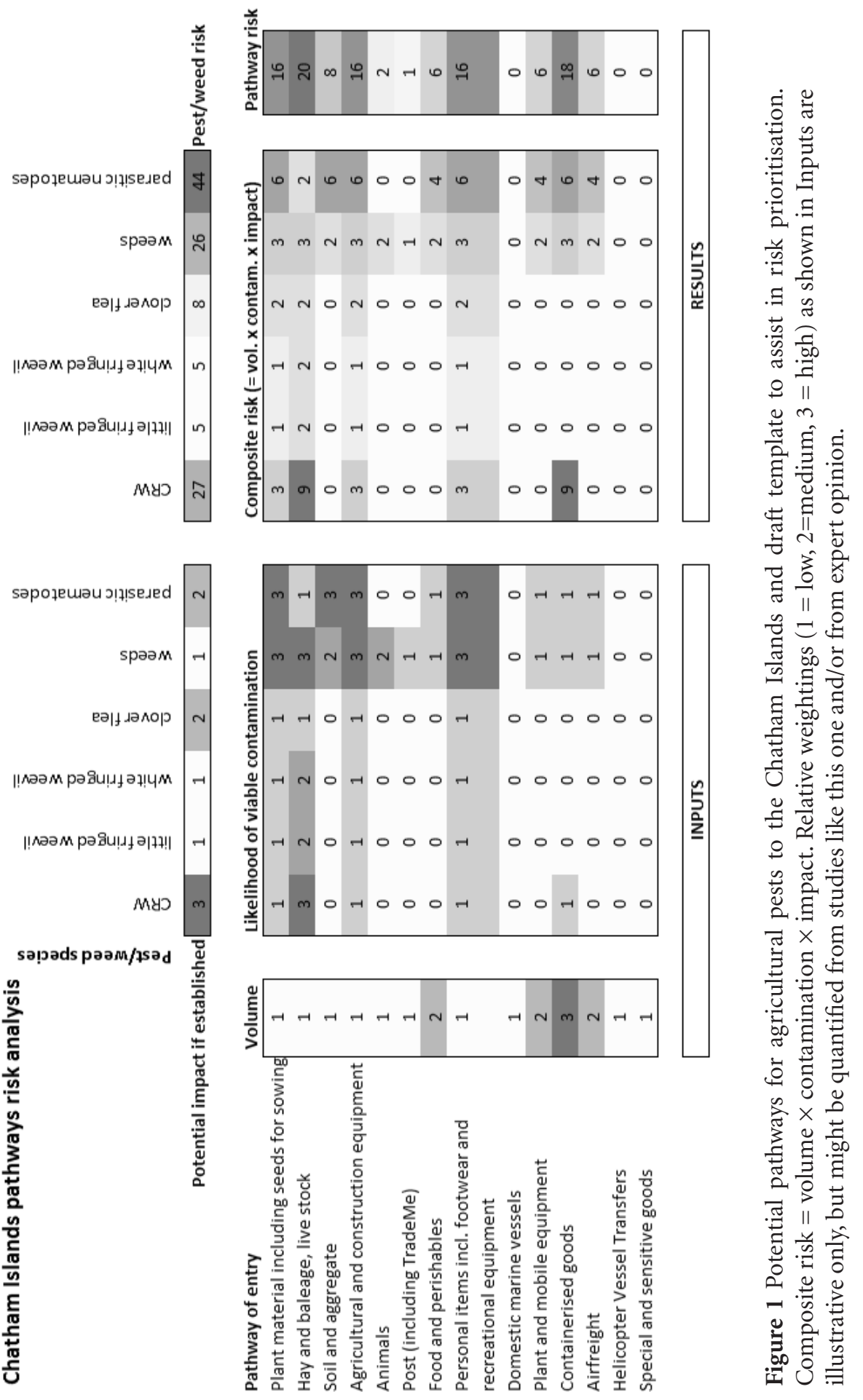


Champion P, James T, Popay I, Ford K 2012. An Illustrated Guide to Common Grasses, Sedges and Rushes of New Zealand. New Zealand Plant Protection Society, Hastings, New Zealand. 208 pp.

Chatham Islands Council 2008. Chatham Islands Pest Management Strategy 2008-2018. (http:// www.cic.govt.nz/documents/2008/07/chathamislands-pest-management-strategy-2008-2018. pdf (accessed 01 June 15). 91 pp.

Courtright EM, Wall DH, Virginia RA, Frisse LM, Vida JT, Thomas WK 2000. Nuclear and mitochondrial DNA sequence diversity in the Antarctic nematode Scottnema lindsayae. Journal of Nematology 32: 143-153.

Curtis NR 2011. All aboard the emergent ark: Biogeography of the dune insect fauna of New Zealand and Chatham Island. $\mathrm{PhD}$ thesis, Lincoln University, New Zealand. 218 pp.

Doncaster CC 1962. A counting dish for nematodes. Nematologica 7: 334-336.

Duncan LW, Moens M 2006. Migratory Endoparasitic Nematodes. In: Perry RN, Moens $\mathrm{M}$ ed. Plant Nematology. CABI, Wallungford. Pp. 123-152.

Edgar E, Connor HE 2000. Flora of New Zealand Volume V: Gramineae (Grasses). Manaaki Whenua Press, Lincoln, New Zealand.

Emberson RM 2003. The beetle fauna (Coleoptera) of the Chatham Islands, with additional species, corrections, and updated taxonomic, biological and distributional information to end 2002. Lincoln University report, Lincoln, New Zealand. 53 pp.

Ferguson CM, McNeill MR, Phillips CB, Hardwick S, Barton DM, Kean JM 2012. Status of clover root weevil and its biocontrol agent in the South Island after six years. Proceedings of the New Zealand Grassland Association 74: 171-176.

Floyd R, Abebe E, Papert A, Blaxter M 2002. Molecular barcodes for soil nematode identification. Molecular Ecology 11: 839-850.

Gerard PJ, Barringer JRF, Charles JG, Fowler SV, Kean JM, Phillips CB, Tait AB, Walker GP 2013. Potential effects of climate change on biological control systems: case studies from New Zealand. BioControl 58: 149-162.
Goldberg J, Trewick SA 2011. Exploring phylogeographic congruence in a continental island system. Insects 2: 369-399.

Hellmann JJ, Byers JE, Bierwagen BG, Dukes JS 2008. Five potential consequences of climate change for invasive species. Conservation Biology 22: 534-543.

Hooper DJ, Evans K 1993. Extraction, identification and control of plant parasitic nematodes. In: Evans K, Trudgill DL, Webster JM ed. Plant parasitic nematodes in temperate agriculture. $\mathrm{CAB}$ International, Wallingford. Pp. 1-59.

Kaplan DT, Thomas WK, Frisse LM, Sarah JL, Stanton JM, Speijer PR, Marin DH, Opperman $\mathrm{CH}$ 2000. Phylogenetic analysis of geographically diverse Radopholus similis via rDNA sequence reveals a monomorphic motif. Journal of Nematology 32: 134-142.

Knight KWL, Barber CJ, Page GD 1997. Plantparasitic nematodes of New Zealand recorded by host association. Journal of Nematology 29: 640-656.

MacFarlane RP 1979. Notes on insects of the Chatham Islands. New Zealand Entomologist 7: 64-70.

MacFarlane RP, Morales CF, Craw RC 1991. Chatham Island insect survey, March 1991. DSIR Plant Protection, Research Report. DSIR, Auckland, New Zealand. 47 pp.

McNeill MR, Goldson SL, Proffitt JP, Phillips CB, Addison PJ 2002. A description of the commercial rearing and distribution of Microctonus hyperodae (Hymenoptera: Braconidae) for biological control of Listronotus bonariensis (Kuschel) (Coleoptera: Curculionidae). Biological Control 24: 167175.

Mercer CF, Bell NL, Yeates GW 2008. Plantparasitic nematodes on pasture in $\mathrm{New}$ Zealand. Austral Plant Pathology 37: 279-288.

Moore JL, Rout TM, Hauser CE, Moro D, Jones M, Wilcox C, Possingham HP 2010. Protecting islands from pest invasion: optimal allocation of biosecurity resources between quarantine and surveillance. Biological Conservation 143: 1068-1078. 
Popay I, Champion P, James T 2010. An Illustrated Guide to Common Weeds of New Zealand. New Zealand Plant Protection Society, Christchurch, New Zealand. 448 pp.

Ross JL, Ivanova ES, Spiridonov SE, Waeyenberge L, Moens M, Nicol GW, Wilson MJ 2010. Molecular phylogeny of slug-parasitic nematodes inferred from 18S rRNA gene sequences. Molecular Phylogenetics and Evolution 55: 738-743.

Siddiqi MR 2000. Tylenchida: Parasites of Plants and Insects. CABI Publishing, Wallingford, UK.

Watson RN, Mercer CF 2000. Pasture nematodes: the major scourge of white clover. Proceedings of the New Zealand Grasslands Association 62: 195-199.
Venette CR, Koch RL 2009. IPM for Invasive Species. In: Radcliffe EB, Hutchison WD, Cancelado RE ed. Integrated Pest Management Concepts, Tactics, Strategies and Case Studies. Cambridge University Press, Cambridge, UK. Pp. 424-430.

Webb CJ, Sykes WR, Garnock-Jones PJ 1988. Naturalised Pteridophytes, Gymnosperms, Dicotyledons. Flora of New Zealand, Vol. 4, Botany Division, DSIR, Christchurch.

Wittenberg R, Cock MJW 2001. Early Detection. In: Witteburg R, Cock MJW ed. A toolkit of best prevention and management practices. CAB International, Wallingford, UK. Pp. 103139. 